\title{
ТЕНДЕНЦІЇ РОЗВИТКУ ГОТЕЛЬНО-РЕСТОРАННИХ ПІДПРИЕМСТВ ЯК ФАКТОР ВПЛИВУ НА ПІДГОТОВКУ МАЙБУТНІХ ФАХІВЦІВ СФЕРИ ОБСЛУГОВУВАННЯ
}

\section{В. Б. Сопіга, Т. П. Сорока}

Тернопільський національний педагогічний університет імені В.Гнатюка

вул. М. Кривоноса, 2, 46027, м. Тернопіль, Україна. E-mail: victorsopiga @ gmail.com

Окреслено, що на підготовку фахівців сфери послуг впливають такі тенденції у готельно-ресторанних підприємствах: поширення здорового швидкого харчування; розвиток діяльності фудтраків («кафе на колесах»); популяризація крафтових напоїв; використання харчових $3 \mathrm{~d}$ принтерів; змішування різних стилів та концепцій у ресторанній справі; удосконалення безпеки клієнтів та охорони праці працівників за допомогою автоматизованих комплексних систем захисту. Зосереджено увагу на тенденціях розвитку інформаційних технологій у готельно-ресторанних підприємствах, що впливають на підготовку відповідних фахівців, а саме: використання сайтів, мобільних додатків та інтерактивного меню; здійснення замовлення по Інтернету; впровадження систем веб-моніторингу діяльності працівників; розширення можливостей оплати послуг через віртуальні платіжні системи.

Ключові слова: тенденції у готельно-ресторанній справі, готельно-ресторанні підприємства, підготовка фахівців сфери обслуговування.

\section{ТЕНДЕНЦИИ РАЗВИТИЯ ГОСТИНИЧНО-РЕСТОРАННОГО КОМПАНИЙ КАК ФАКТОР ВЛИЯНИЯ НА ПОДГОТОВКУ БУДУЩИХ СПЕЦИАЛИСТОВ СФЕРЫ ОБСЛУЖИВАНИЯ}

\section{В. Б. Сопига, Т. П. Сорока}

Тернопольский национальный педагогический университет имени В. Гнатюка

ул. М. Кривоноса, 2, 46027., Г. Тернополь, Украина. E-mail: victorsopiga @ gmail.com

Определено, что на подготовку специалистов сферы услуг влияют такие тенденции в гостиничноресторанных предприятиях: распространение здорового быстрого питания; развитие деятельности фудтраков («кафе на колесах»); популяризация крафтовых напитков; использование пищевых $3 \mathrm{~d}$ принтеров; смешивания различных стилей и концепций в ресторанном деле; усовершенствования безопасности клиентов и охраны труда работников с помощью автоматизированных комплексных систем защиты. Сосредоточено внимание на тенденциях развития информационных технологий в гостинично-ресторанных предприятиях, влияющие на подготовку соответствующих специалистов, а именно: использование сайтов, мобильных приложений и интерактивного меню; осуществления заказа по Интернету; внедрение систем веб-мониторинга деятельности работников; расширение возможностей оплаты услуг через виртуальные платежные системы.

Ключевые слова: тенденции в гостинично-ресторанном деле, гостинично-ресторанные предприятия, подготовка специалистов сферы обслуживания.

АКТУАЛЬНІСТЬ РОБОТИ. Сучасні освітні реалії вимагають нових підходів до викладання навчальних дисциплін. Зокрема, динамічність вимог та мобільність студентів потребують нових підходів до формування змісту підготовки кадрів з урахуванням тенденцій у відповідній галузі.

У процесі підготовки фахівців сфери обслуговування важливо враховувати тенденції у готельноресторанних підприємствах. Адже кваліфікований випускник закладу вищої освіти повинен бути готовий до актуальних викликів ринку та суспільства.

Проблемами підготовки фахівців сфери послуг у вищих навчальних закладах займалися провідні науковці, зокрема:

- форми та методи викладання фахових дисциплін за напрямом Готельно-ресторанна справа досліджували О. Василенко, Н. Зубар, О. Кашинська [1; $2 ; 3]$;

- системні та концептуальні підходи до підготовки фахівців готельно-ресторанної сфери розглядали А. Віндюк, І. Носова, Л. Хаєт [4; 5] та ін.

Окремі аспекти тенденцій розвитку готельноресторанних підприємств досліджувалися низкою вчених, а саме:

- роль інновацій у готельно-ресторанному підприємстві висвітлювали I. Андрющенко, С. Бурий,
К. Галасюк, Н. Прилепа, Г. Соколюк, О. Чумак [6; 7; $8 ; 9]$

- особливість розвитку готельно-ресторанного бізнесу в Україні розкривали О. Борисова, Л. Малюта， Л. Мельник, Г. Нагорняк， Р. Шерстюк $[10 ; 11]$;

- тенденції в обслуговуванні клієнтів окреслювали I. Верезомська, Л. Гірняк, О. Крупський, В. Сопіга $[12 ; 13 ; 14]$ та ін. .

Однак у наукових студіях недостатньо розкрито вплив тенденцій розвитку готельно-ресторанних підприємств на підготовку фахівців сфери послуг. Потребують подальшого наукового обгрунтування особливості формування змісту підготовки фахівців сфери обслуговування 3 урахуваннях динамічних змін у відповідній галузі.

Мета статті - розкрити основні тенденції у готельно-ресторанних підприємствах, які слід враховувати при підготовці фахівців сфери обслуговування у закладах вищої освіти.

Методи та методики дослідження: аналіз науково-педагогічних публікацій з метою уточнення стану дослідженості проблеми; аналіз та систематизація наукової літератури, інтернет-джерел, спостереження і вивчення досвіду роботи співробітників готельно-ресторанних підприємств для виокремлен- 
ня актуальних тенденцій у відповідній сфері; синтез і узагальнення даних для обгрунтування доцільності врахування основних тенденцій готельноресторанної індустрії у процесі підготовки фахівців сфери послуг.

МАТЕРІАЛ І РЕЗУЛЬТАТИ ДОСЛІДЖЕНЬ. Зауважимо, що в багатьох регіонах України відзначається тенденція до створення готельних підприємств малих форм, які успішно конкурують із великими засобами розміщення, тому що можуть запропонувати туристам більш якісне, персоніфіковане обслуговування на фоні більш низьких цін.

У процесі вдосконалення маркетингових технологій, менеджери готельно-ресторанних підприємтсв намагаються просунути свої послуги, показати 3 найкращої сторони власну культуру та якість обслуговування різними способами, у тому числі за допомогою інтернет-технологій.

3 метою розширення менеджерських та маркетингово-рекламних можливостей низка ресторанів популяризують послуги в інтернеті створюючи фірмові веб-сайти, розміщуючи їх у пошукових, комерційно-ділових, туристично-готельних інформаційних системах.

В умовах сьогодення, провідні готельноресторанні комплекси використовують такі інтернет-технології:

- сайти готелів, ресторанів, їх ланцюгів;

- сайти та інформаційні сторінки довідників міст, баз відпочинків, туроператорів тощо;

- сторінки у соціальних мережах;

- мобільні додатки, які дають змогу ознайомитися 3 переліком та характеристикою готелів, ресторанів тощо;

- мобільні додатки конкретних закладів відпочинку чи громадського харчування, в яких передбачено вибір послуг готельно-ресторанного комплексу, бронювання місць, чат з адміністратором тощо;

- оплата послуг та в разі необхідності відшкодування коштів через віртуальні платіжні системи.

У закладах ресторанного господарства простежуються тенденції розвитку сучасних технологій за різними напрямами, а саме:

- $\quad$ створення ресторанів за типом «FreeFloor»;

- $\quad$ запровадження фуд-кортів;

- створення та вдосконалення роботи ресторанних господарств з різноманітними концепціями;

- розширення мережі віртуальних ресторанів або «ресторанів без столиків», що забезпечують замовлення по мережі Інтернет та доставку споживачеві;

- приготування страв у присутності відвідувачів; організація обслуговування за системою кейтерінг тощо [9].

В умовах складних економічних перетворень українські ресторатори адаптують традиційні рецепти та при формуванні меню зміщують акценти в бік застосування інгредієнтів, зібраних 3 приватних фермерських господарств. При цьому позитивною тенденцією сучасного українського ресторанного бізнесу є актуалізація «здорового харчування». Широкого поширення набуває філософія «повільної їжі» або гастрономічна концепція «слоуфуд» (англ. slowfood - повільна їжа), яка передбачає задоволення смачними і корисними стравами. Відповідно до концепції «слоуфуд» овочі та фрукти піддаються мінімальній тепловій обробці, щоб зберегти натуральний смак [10].

Завдяки цим тенденціям на вулицях міст 3'являються нові типи підприємств ресторанного господарства: салат-бари, суп-кафе, а кількість закладів, що пропонують вегетаріанські страви збільшується. Вважаємо, що формуючи зміст підготовки фахівців сфери послуг доцільно враховувати зазначені тенденції, зокрема на заняттях варто розкривати особливості організації здорового харчування людей, які довго перебувають у дорозі.

Мода на «здорове харчування» обумовлює збільшення концентрації уваги рестораторів на пошуку нових гастрономічних детермінантів відповідно до вимог та запитів споживачів. Наприклад, сьогодні спостерігається тенденція збільшення кількості ресторанів, в яких подають безглютеновий хліб, десерти тощо.

Основний тренд щодо напоїв останніх років крафт. В меню закладів ресторанного господарства 3'явилася велика кількість крафтового бренді, віскі, джина, інших напоїв.

Підвищений інтерес до смачного та здорового харчування вплинув на появу нових напрямків в ресторанному бізнесі. За останній рік став популярним формат «оpen kitchen» або «відкритих кухонь», коли відвідувачі можуть спостерігати за процесом приготування, оцінювати якість продуктів і рівень майстерності кухаря. Безумовно, даний інноваційний напрямок розвитку сфери ресторанного бізнесу заслуговує на увагу. Оскільки клієнти бачать весь робочий процес зсередини, вони не сумніваються в свіжості продуктів і якості роботи персоналу. До того ж, очікування в ресторані проходить набагато цікавіше, ніж просто вид 3 вікна або екран телевізоpa [9].

Існує тенденція до збільшення запитів суспільства щодо повноцінних обідів-ланчів, тому і зростає популярність пересувних закладів, які пропонують якісну вуличну їжу на рівні традиційних закладів. Також існує тенденція розвитку фудтраків («кафе на колесах») різного типу: кав'ярні, морозиво, кондитерські, гриль-бари, традиційні фастфуди, піцерії і навіть пересувні пивоварні.

Вже загальновідомо, що сучасні фудтраки - це повністю обладнані автомобілі з приготування та продажу їжі на винос, в яких дійсно приємно купувати. Слід зазначити, що сам фудтрак є не тільки засіб обслуговування, а й пересувною рекламою бренду. Головним плюсом такого бізнесу $є$ можливість зміни локації, в залежності від щільності вуличного потоку і часу доби .

3 одного боку у готельно-ресторанному комплексі не має потреби у фудтраках, бо готель є стаціонарним об’єктом. Однак майбутнім фахівцям сфери обслуговування варто знати, що фудтраки у даному випадку можна розгляди як опції додаткових послуг. Так, у готельно-ресторанному комплексі можна ввести послугу відпочинку, анімацій своїм клієнтам 
за межами знаходження закладу, наприклад у лісі, парку, полонині, в залежності від того в якій місцевості знаходиться це підприємство. У такому разі, при виїзді гостей на кілька годин, буде в нагоді використання фудтраку.

Широке різноманіття різних видів закладів ресторанного господарства безумовно загострює конкуренцію у даній сфері. Готельно-ресторанний бізнес складається 3 тисячі дрібниць, де будь-який найменший нюанс відіграє важливу роль. Для успішного готельно-ресторанного бізнесу менеджерам необхідно максимально використовувати потенціал свого закладу і одночасно управляти різними каналами взаємодії з клієнтами. 3 метою підвищення лояльності споживачів, кожен сучасний менеджер повинен прагнути до підвищення рівня якості обслуговування з найменшими витратами.

Формування конкурентних переваг готельноресторанного господарства здійснюється на основі пошуку інноваційних детермінантів як в кулінарній майстерності, так і в культурі обслуговування, що значно підвищує імідж підприємства готельноресторанного бізнесу та сприяє зміцненню рівня його конкурентоспроможності. Саме тому, важливо щоб майбутній фахівець сфери послуг орієнтувався в інноваційних підходах до обслуговування, менеджменту, аналізу ринку тощо.

До інноваційних технологій в готельноресторанному господарстві відноситься застосування інтерактивного (електронного) меню, екранупланшету на столах, сенсорного дисплею, застосування QR-коду, технології LED оповіщення, харчові 3-D принтери, сенсорні виробники їжі, використання тривимірних проекцій і відео для демонстрації приготування страв, автоматизація та інформатизація процесів на підприємствах, використання web- i телекомунікаційних технологій тощо [11]. Зазначені інноваційні технології коштують досить дорого, тому зараз не завжди використовуються, однак тенденції збільшення використання цих засобів продовжується, тому майбутні фахівці сфери послуг повинні в цьому бути компетентними.

Науково-технічний прогрес обумовив тенденцію впровадження в закладах ресторанного бізнесу електронного та інтерактивного меню. Електронне меню $є$ аналогом паперового, яке дозволяє власнику закладу в будь-який момент легко додати або виключити з асортименту необхідну страву або напій. При цьому більше не потрібно витрачати час і гроші на дорогі послуги дизайнерів і друкарень кожен раз, коли потрібно доповнити або видозмінити меню [11]. Електронне меню супроводжується фотографією страви, а також містить перелік інгредієнтів, які входять до їі складу.

Отже, у змісті підготовки фахівців готельноресторанної справи важливо передбачити, серед іншого, вивчення особливостей обслуговування за допомогою електронного списку послуг, що є каналом зв'язку між клієнтами і підприємствами, рестораторами. Електронні технології дають змогу швидко редагувати меню, список послуг, прайс і вносити в нього відповідні корективи. Крім цього, вони дають змогу:
- підвищувати якість обслуговування та збільшувати кількість постійних клієнтів закладу;

моніторити детальну статистику замовлень номерів, послуг, страв тощо. Ресторатор в будь-який момент може переглянути.

Щодо ролі і місця QR-коду для електронного обслуговування то зазначимо, що він сприяє наданню нових можливостей для взаємодії «online» готельноресторанних господарств і споживачів.

Також, одним із сучасних напрямків розвитку інноваційних технологій в готельно-ресторанному бізнесі $є$ технології LED оповіщення, про яку варто знати майбутнім фахівцям (випускникам відповідних закладів вищої освіти). Ця технологія дає змогу полегшити процес організації роботи готельноресторанного підприємства, зробити його більш зрозумілим і ненав'язливим. Інтеграція технології LED оповіщення сприяє своєчасному оповіщенню персоналу готельно-ресторанного підприємства щодо виконані завдання, наприклад, готовність замолених послуг, готовність страви, готовність до використання спортивного інвентарю, конференцзалів, посуду тощо.

Використання новітніх інформаційних технологій призводить до стрімкого розвитку індустрії гостинності. Відповідно акцентується увага на інноваціях через попит туристів до персонального одноосібного обслуговування.

Переспективою в системі управління готельноресторанним підприємством $є$ інноваційна система web-моніторингу, яка здатна записувати порушення в роботі працівника, фіксувати відхилення санітарних норм, безпеки праці тощо. Ця технологічна система дає можливість менеджменту оцінити рівень підготовленості та відповідальності співробітників готельно-ресторанного господарства.

При виборі готельно-ресторанного підприємства для клієнтів важливо, як там здійснюється харчування, рівень ресторану тощо.

Зауважимо, що не тільки великі готельноресторанні комплекси, а й більшість усіх ресторанів сьогодні можуть запропонувати онлайн-сервіс, де представлена українська, європейська, японська та інші кухні. Можна сказати, що для більшості сучасних клієнтів інтернет-сервіс не буде чимось надто не звичним, люди звикають користуватися такими благами цивілізації в усіх напрямах, у тому числі й щодо вибору готельно-ресторанних послуг.

Одним із найбільш популярних напрямів розвитку в ресторанних господарствх є стиль «фьюжн» або «cross-cooking» (с англ. cross - «перехрестя»; cooking - «готування харчів»). Ресторатори змішують стилі та концепції, щоб задовольнити клієнта. У зв'язку з цим зростає інтерес до цих закладів. Також змінюються формати подачі страв, 3'являються «finger-food» (фуршет, де харчуються тільки руками) i «tapas» (на стіл ставиться одна тарілка - на усіх, що гарно підходить для бізнес-ланчів) [10].

Поряд із вищезазначеними тенденціями, у сучасному світі важливе місце посідають питання безпеки клієнтів та персоналу, охорони праці тощо. При цьому безпеку можна розглядати як один із основних компонентів якості та культури обслуговування 
у готельно-ресторанних підприємствах. Адже якість продукції, послуг, приміщень має бути зорієнтована передусім на безпеку споживача, а культура обслуговування повинна бути організована так, щоб це не вплинуло негативно на безпеку праці та життєдіяльності.

Зокрема, у готельно-ресторанних господарствах впроваджують різні технічні системи, які спрямовані на забезпечення безпеки життєдіяльності клієнтів та охорони праці персоналу, зокрема: системи пожежної безпеки, електробезпеки, кібербезпеки, організаційні заходи для персоналу (відповідні навчання, інструктажі, медогляди тощо), а також захист від злочинців, крадіжок та ін.

У провідних готельно-ресторанних комплексах існує тенденція до встановлення автоматизованих комплексних систем захисту. Наприклад, якщо в таких готелях спрацьовують датчики сигналізації, тоді відкриваються електронні замки запасних виходів, діє система пожежогасіння, сповіщення тощо. Так, у готелі, де може бути більше трьох тисяч пожежних сповіщувачів, а кожен датчик адресований $і$ контролюється в режимі реального часу [7].

Тенденції у готельно-ресторанних підприємствах щодо удосконалення безпеки гостів важливо враховувати при викладання студентам особливостей організації безпечних, нешкідливих умов праці працівників та проживання і харчування клієнтів.

ВИСНОВКИ. У процесі підготовки майбутніх фахівців сфери послуг важливо враховувати такі сучасні тенденції у готельно-ресторанних підприємствах:

впровадження інформацій технологій у процесі обслуговування, зокрема використання інтерактивного (електронного) меню, здійснення замовлення по інтернету або за допомогою спеціальних терміналів безпосередньо у готельних чи ресторанних підприємствах;

- поширення здорового швидкого харчування (якісна вулична їжа); колесах»); розвиток діяльності фудтраків («кафе на

- $\quad$ популяризація крафтових напоїв;

- $\quad$ використання харчових 3d принтерів;

- впровадження систем веб-моніторингу в діяльність працівників;

- $\quad$ змішування різних стилів та концепцій у ресторанній справі;

удосконалення безпеки клієнтів та охорони праці співробітників за допомогою автоматизованих комплексних систем захисту.

Відповідно до окреслених тенденцій розвитку готельно-ресторанних підприємств, у зміст підготовки фахівців сфери обслуговування, поряд із традиційними компонентами, варто включати питання які передбачають:

- вивчення особливостей організації здорового харчування подорожуючих людей;

- набуття умінь використовувати сучасні інформаційні технології, що $є$ каналом зв'язку між клієнтами готельно-ресторанних підприємств та обслуговуючим персоналом;
- ознайомлення з сучасними технологічними новинками приготування страв, 3 особливостями поєднання й модернізації різних стилів, форм та методів обслуговування;

засвоєння знань про сучасні системи безпеки клієнтів і працівників підприємств сфери послуг.

Подальших наукових пошуків потребують проблеми наступності підготовки фахівців сфери обслуговування з урахуванням тенденцій у відповідній сфері. Варто шукати нові підходи до вдосконалення змістового взаємозв'язку між аудиторними дисциплінами та навчальними практиками.

\section{ЛІТЕРАТУРА}

1. Василенко О. Інноваційні технології та методи навчання управлінських кадрів закладів ресторанного господарства. Збірник наукових праиь Уманського державного педагогічного університету імені Павла Тичини. 2015. Вип. 1. С. 72-78.

2. Зубар Н. Формування компетентності педагогів професійного навчання 3 готельно-ресторанної справи. Наукові записки Кіровоградського державного педагогічного університету імені Володимира Винниченка. Серія: Проблеми методики фізикоматематичної $i$ технологічної освіти. 2015. Вип. 7(1). С. 36-42.

3. Кашинська О. С. Використання веб-квестів у процесі підготовки студентів спеціальності «Готельно-ресторанна справа». Вісник Луганського національного університету імені Тараса Шевченка. Педагогічні науки. 2017. № 1(2). С. 108-115.

4. Віндюк А. В. Професійна підготовка майбутніх фахівців з готельно-курортної справи в умовах ступеневої освіти: теорія та методика: монографія. Запоріжжя: КПУ, 2011. 340 с.

5. Носова І. О., Хаєт Л. Г. Тренінгові методи у розвитку професійних компетенцій фахівців готельно-ресторанної справи. Інформаційні технології в освіті, науи̧і та виробництвві, 2013. Вип. 1(2). C. 285-292.

6. Чумак О. В., Андрющенко I. С. Аналіз стану й оцінка тенденцій показників розвитку підприємств ресторанного господарства. Бізнес Інформ. 2014. № 12. С. 307-313.

7. Бурий С. А. Інноваційний потенціал у сфері готельно-ресторанного бізнесу та туризму. Вісник Хмельницького національного університету. Економічні науки. 2014. № 5. Т. 2. С. 201-205.

8. Галасюк К. А. Аналіз існуючих методик оцінки інноваційного потенціалу підприємств сфери туризму. Науковий вісник Миколаївського національного університету імені В.О. Сухомлинського. Економічні науки. 2015. № 1. С. 98-102.

9. Прилепа Н. В. Соколюк Г. О. Інноваційні технології у сфері ресторанного бізнесу. Вісник Хмельницького національного університету. Економічні науки. 2014. № 4. Т. 2. С. 162-164.

10. Борисова О. В. Тенденції розвитку готельно-ресторанного бізнесу в Україні. Економічна стратегія $і$ перспективи розвитку сфери торгівлі та послуг. 2012. Вип. 1(2). С.331-338.

11. Нагорняк Г., Малюта Л., Мельник Л., Шерстюк Р. Організаційно-економічні засади розвитку 
інноваційного процесу вітчизняних закладів готельно-ресторанної сфери в туристичному контексті. Сочіально-економічні проблеми $і$ держава. 2017. Вип. 1(16). С. 148-158. URL: http://sepd.tntu.edu.ua/images/stories/pdf/2017/17nhsvt k.pdf (дата звернення: 10.03.2019).

12. Верезомська I. Г. Формування корпоративної культури та імідж готельного підприємства. Науковий вісник Полтавського університету економіки і торгівлі. Серія: Економічні науки. 2011. № 6(2). С. 136-140.
13. Гірняк Л. І., Сопіга В. Б. Формування культури та якості обслуговування у готельноресторанних підприємствах. Науковий вісник Ужгородського начіонального університету. Серія: Міжнародні економічні відносини та світове господарство. Ужгород, 2018. Вип. 21. Ч 1. С. 50-55.

14. Крупський О. П. Організаційна культура туристичного підприємства як індикатор його інноваційного потенціалу. Бізнес інформ. 2014. № 9. C. 200-204.

\section{TENDENCIES IN THE DEVELOPMENT OF HOTEL AND RESTAURANT ENTERPRISES AS AN INFLUENCE FACTOR OF TRAINING OF SPECIALISTS IN THE SERVICE TRADES}

\section{Sopiha, T. Soroka}

Ternopil Volodymyr Hnatiuk National Pedagogical University

vul. Maxyma Kryvonosa, 2, 46027, Ternopil, Ukraine. E-mail: victorsopiga@ gmail.com

Purpose. The article reveals the main tendencies in the hotel and restaurant enterprises which should be taken into account in the training of specialists of service in institutions of higher education. Methodology. The research is conducted using the analysis and systematization of data from scientific literature and from Internet. The data is synthesized and summarized about tendencies in hotels and restaurants. Findings. The research reveals the main trends in the hotel and restaurant business, in particular: the spread of healthy fast food; development of the activities of the food tracker; popularization of craft drinks; use of food 3d printers; mixing different styles and concepts in the restaurant business; improving customer safety and employee safety through automated comprehensive security systems. The focus is on the development of information technology in hotel and restaurant enterprises that affect the training of relevant professionals, namely: the use of sites, mobile applications and interactive menus; ordering on the Internet; implementation of web monitoring systems for employees; expanding the ability to pay for services through virtual payment systems. The article states that these tendencies predetermine on the training of specialists in higher education institutions in the direction of hospitality. Originality. The scientific novelty lies in the fact that modern trends in the modernization of the process of providing services in hotels and restaurants are disclosed and their impact on the training of the fields of service is ostended. Practical value. The practical value of the research includes the possibility to improve curricula, programs, content of training of the fields of service, taking into account modern tendencies in the hotel and restaurant business. Conclusions. The content of training specialists in the field of service should include the following issues: study of the peculiarities of organization of healthy nutrition of traveling people; acquiring the skills to use modern information technologies, which is the channel of communication between customers of hotel and restaurant enterprises and service personnel; acquaintance with modern technological novelties of cooking, with features of combination and modernization of different styles, forms and methods of service; mastering the knowledge about modern safety systems of clients and employees of service enterprises.

Key words: tendencies in the hotel and restaurant business, hotel and restaurant enterprises, training of specialists in the field of service.

\section{REFERENCES}

1. Vasylenko, O. (2015), "Innovatsiini tekhnolohii ta metody navchannia upravlinskykh kadriv zakladiv restorannoho hospodarstva" [Innovative technologies and methods of training managerial staff of restaurants], Zbirnyk naukovykh prats Umanskoho derzhavnoho pedahohichnoho universytetu imeni Pavla Tychyny [Collection of scientific works of Pavo Tychyna Uman State Pedagogical University], vol. 1. pp. 72-78.

2. Zubar, N. (2015), "Formuvannia kompetentnosti pedahohiv profesiinoho navchannia $\mathrm{z}$ hotelnorestorannoi spravy" [Formation of competence of teachers of professional training in hotel and restaurant business], Naukovi zapysky Kirovohradskoho derzhavnoho pedahohichnoho universytetu imeni Volodymyra Vynnychenka. Seriia: Problemy metodyky fizyko-matematychnoi $i$ tekhnolohichnoi osvity [Scientific notes Volodymyr Vynnychenko Kirovograd State Pedagogical University. Series: Problems of Methodology of Physical-Mathematical and Technological Education], vol. 7 (1), pp. 36-42.
3. Kashynska, O. Ye. (2017), "Vykorystannia vebkvestiv u protsesi pidhotovky studentiv spetsialnosti "Hotelno-restoranna sprava»" [Using web quests in the process of preparing students for the specialty «Hotel and restaurant business»], Visnyk Luhanskoho natsionalnoho universytetu imeni Tarasa Shevchenka. Pedahohichni nauk [Bulletin of Taras Shevchenko National University of Lugansk. Pedagogical sciences], vol 1(2). pp. 108-115.

4. Vindiuk, A. V. (2011), Profesiina pidhotovka maibutnikh fakhivtsiv $z$ hotelno-kurortnoi spravy $v$ umovakh stupenevoi osvity: teoriia ta metodyka [Professional training of future specialists in hotel and resort business in conditions of advanced education: theory and methodology], KPU, Zaporizhzhia, Ukraine.

5. Nosova, I. O., Khaiet, L. H. (2013), Treninhovi metody u rozvytku profesiinykh kompetentsii fakhivtsiv hotelno-restorannoi spravy [Training methods in the development of professional competencies of specialists in hotel and restaurant business]. Informatsiini tekhnolohii $v$ osviti, nautsi ta vyrobnytstvi [Information 
technology in education, science and production], vol. 1 (2). pp. 285-292.

6. Chumak, O. V., Andriushchenko, I. S. (2014), "Analiz stanu y otsinka tendentsii pokaznykiv rozvytku pidpryiemstv restorannoho hospodarstva" [Analysis of the state and evaluation of tendencies of indicators of development of enterprises of restaurant economy], Biznes inform [Business Inform], vol. 12, pp. 307-313.

7. Buryi, S. A. (2014), "Innovatsiinyi potentsial u sferi hotelno-restorannoho biznesu ta turyzmu" [Innovative potential in the sphere of hotel and restaurant business and tourism], Visnyk Khmelnytskoho natsionalnoho universytetu. Ekonomichni nauky. [Bulletin of the Khmelnytsky National University. Economic Sciences], no. 5, part. 2. pp. 201-205.

8. Halasiuk, K. A. (2015), "Analiz isnuiuchykh metodyk otsinky innovatsiinoho potentsialu pidpryiemstv sfery turyzmu" [Analysis of existing methods for assessing the innovative potential of tourism enterprises]. Naukovyi visnyk Mykolaivskoho natsionalnoho universytetu imeni $V$. O. Sukhomlynskoho. Ekonomichni nauky [Scientific Bulletin of Mykolaiv V.O.Sukhomlynskyi National University], no 1, pp. 98-102.

9. Prylepa, N. V., Sokoliuk, H. O. (2014), "Innovatsiini tekhnolohii u sferi restorannoho biznesu" [Innovative technologies in restaurant business], Visnyk Khmelnytskoho natsionalnoho universytetu. Ekonomichni nauky [Bulletin of the Khmelnytsky National University. Economic Sciences], vol 4, part. 2, pp. 162-164.

10. Borysova, O. V. (2012), "Tendentsii rozvytku hotelno-restorannoho biznesu v Ukraini” [Tendences in the development of hotel and restaurant business in Ukraine], Ekonomichna stratehiia $i$ perspektyvy rozvytku sfery torhivli ta posluh [Economic strategy and prospects for the development of trade and services], vol. 1(2). pp. 331-338.
11. Nahorniak, H., Maluta, L., Melnyk, L., Sherstiuk, R. (2017), “Orhanizatsiino-ekonomichni zasady rozvytku innovatsiinoho protsesu vitchyznianykh zakladiv hotelno-restorannoi sfery $\mathrm{v}$ turystychnomu konteksti" [Organizational and economic principles of innovative development processes of national hotel and restaurant business structures in the tourism context], Sotsialnoekonomichni problemy $i$ derzhava [Socio-Economic Problems and the State], vol 16 (1), pp. 148-158. URL: http://sepd.tntu.edu.ua/

images/stories/pdf/2017/17nhsvtk.pdf (accessed 10, March 2018).

12. Verezomska, I. H. (2011), "Formuvannia korporatyvnoi kultury ta imidzh hotelnoho pidpryiemstva" [Formation of the corporate culture and the image of the hotel company], Naukovyi visnyk Poltavskoho universytetu ekonomiky i torhivli. Seriia: Ekonomichni nauky [Scientific Bulletin of Poltava University of Economics and Trade. Series: Economic Sciences], vol. 6 (2), pp. 136-140.

13. Hirniak, L. I., Sopiha, V. B. (2018), "Formuvannia kultury ta yakosti obsluhovuvannia u hotelno-restorannykh pidpryiemstvakh" [Formation of culture and quality of service in the hotel and restaurant enterprises], Naukovyi visnyk Uzhhorodskoho natsionalnoho universytetu. Seriia: Mizhnarodni ekonomichni vidnosyny ta svitove hospodarstvo [Scientific Bulletin of Uzhgorod National University. Series:International Economic Relations and World Economy], Uzhhorod, vol. 21, part 1, pp. 50-55.

14. Krupskyi, O. P. (2014), "Orhanizatsiina kultura turystychnoho pidpryiemstva yak indykator yoho innovatsiinoho potentsialu" [Organizational culture of the tourist region as an indicator of its innovative potential], Biznes inform [Business Inform], vol 9. pp. 200-204.

Стаття надійшла 01.04.2019. 